\title{
Scenarios of land cover in Karst area of Southwestern China
}

\author{
Zemeng Fan · Jing Li · Tianxiang Yue • \\ Xun Zhou $\cdot$ Anjun Lan
}

Received: 15 September 2014/ Accepted: 20 February 2015/Published online: 6 March 2015

(C) Springer-Verlag Berlin Heidelberg 2015

\begin{abstract}
The method of surface modeling of land cover scenarios (SMLCS) has been improved to simulate the scenarios of land cover in the karst areas of southwestern China. On the basis of the observation monthly climatic data collected from 782 weather stations of China during the period from 1981 to 2010, the climatic scenarios data of RCP26, RCP45 and RCP85 scenarios released by CMIP5, and the land cover current data of China in 2010, the land cover scenarios of southwestern China were respectively simulated. The average total accuracy and Kappa index of SMLCS are 90.25 and $87.96 \%$, respectively. The results show that there would be a very apparent similar variety on the spatial distribution pattern of land cover in the karst areas of southwestern China under all the three scenarios during the period from 2010 to 2100 , but there would have the different change rate. In general, the change rate of land cover type under RCP85 scenario would be the fastest, then under RCP45 scenario, and under RCP26 would be the slowest. From 2010 to 2100, deciduous coniferous forest,
\end{abstract}

Z. Fan $(\bowtie) \cdot$ J. Li $\cdot$ T. Yue $\cdot$ X. Zhou

State Key Laboratory of Resources and Environment

Information System, Institute of Geographic Sciences

and Natural Resources Research, CAS, Beijing 100101, China

e-mail: fanzm@1reis.ac.cn

Z. Fan

Jiangsu Center for Collaborative Innovation in Geographical Information Resource Development and Application,

Nanjing 210023, China

\section{J. Li · X. Zhou}

University of Chinese Academy of Sciences, Beijing 100049, China

A. Lan

School of Geography and Environment Sciences, Guizhou

Normal University, Guiyang 550001, China deciduous broadleaf forest, grassland, cropland, nival area, and desert and bare rock would have a gradual decrease trend, while evergreen coniferous forest, evergreen broadleaf forests, mixed forest, scrublands, wetlands, construction built-up land, and water bodies body would gradually increase in karst areas of southwestern China, in which wetland would have the fastest increase rate $(5.28 \%$ per decade on average), and desert and bare rock would decrease with the fastest rate $(2.34 \%$ per decade on average).

Keywords Surface modeling of land cover scenarios (SMLCS) - Land cover - Scenarios - Karst areas of Southwestern China

\section{Introduction}

Karst areas, as a fragile and vulnerable ecological environment, are more sensitive to climate change and human activities (Whittaker 1972; Solomon 1986; Belotelov et al. 1996; Hochstrasser et al. 2002; Guo et al. 2013; Li et al. 2014). The total area of karst terrains in China is approximately one-third area of Chinese territory, which type includes bare karst, covered karst and buried karst (Yuan 1993). Karst areas in southwestern China, as one of the most typical, complex and extensive karst landform in the world (Sweeting 1993), record the change process of ecological environment under different geological, climatic, hydrological and biological conditions (Guo et al. 2013; Marke et al. 2013), which administratively includes Yunnan, Guizhou, Sichuan, Chongqing and Guangxi (Fig. 1). With the rapid socioeconomic development, rocky desertification of karst areas in southwestern China has been deteriorated that includes serious soil erosion, extensive exposure of basement rocks, drastic decrease of soil 


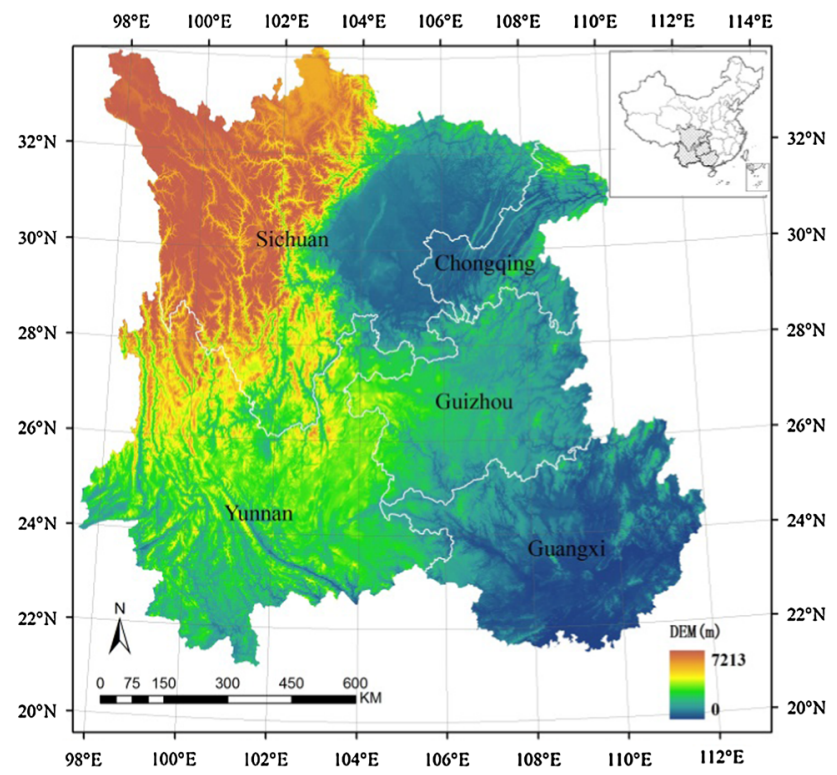

Fig. 1 A digital elevation model of karst areas in southwestern China

productivity, and the appearance of a desert-like landscape (Yuan 1997; Wang et al. 2004; Ying et al. 2014), due to the high population pressure, and more and more irrational, intensive land use and resources exploitation (Ying et al. 2014).

Since the early 1990s a continuing effort to facilitate understanding of the factors causing karst rocky desertification (Sweeting 1993; Huang and Cai 2007; Liu et al. 2008; Li et al. 2009a, b, c; Yang et al. 2011, 2013; Peng et al. 2011) and the eligible ways of reducing karst rocky desertification in southwestern China (Cai 1999; Yang et al. 2006; Yang and Jiang 2011) have been under development. Lots of quantitative analysis methods have been developed to recognize the change in trend of Land cover of karst areas in southwestern China (Cai 1999; Wang and Li 2007; Li et al. 2009a, b, c; Xiong and Chen 2010; Peng et al. 2011; Wu et al. 2011; Yang et al. 2013; Ying et al. 2014). However, the related studies mainly focus on analyzing the history changes and rarely involving the scenarios of land cover in karst areas of western China. Land cover change, as the primary driver of changes in biodiversity (Foley et al. 2005; Sala et al. 2000), directly impacts biogeochemical cycling, soil erosion and ecological diversity (Chapin et al. 2000), and affects the ability of biological systems to support human needs by altering ecosystem services (Vitousek et al. 1997; Yue et al. 2007; Fan et al. 2013a). Thus, quantitatively simulating the land cover scenarios is an important way for understanding the driving mechanism underlying land cover change in Karst area (Yu and Yang 2002; Li et al. 2014).
There are many models developed for simulating the land cover scenarios since 2000s, which can be distinguished into the four categories of statistical models, stochastic models, dynamic models and integrated models (Yue et al. 2007). However, there are some drawbacks in all those models. For example, the land cover scenarios of the IPCC's Special Report on Emissions Scenarios do not include the effect of climate change on future land cover (Arnell et al. 2004), the probabilistic cellular automata model (Solecki and Oliveri 2004) is limited to simulating urban land cover scenarios, the model of conversion of land use and its effects (CLUE) (Verburg et al. 2002) emphasize agricultural ecosystem, the input-output model cannot address the location of land cover change (Hubacek and Sun 2001), the land use change modeling kit (Niehoff et al. 2002) is limited to simulating land cover scenarios on watershed scale, and the early versions of the method of surface modeling of land cover scenarios (SMLCS) (Fan 2005; Yue et al. 2007) do not consider the policy effects of national nature reserve (NNR) and basic farmland protection. So, this paper aims to improve the SMLCS for simulating the scenarios of land cover in Karst areas of Southwestern China and analyzing the potential changes spatial distribution during the period from 2010 to 2100 .

\section{Data and methods}

\section{Datasets}

The bioclimatic data used to operate SMLCS include the observation data and scenario data. Monthly temperature and precipitation data from 1981 to 2010 were collected from 782 weather stations of China. Scenarios data were produced from the World Climate Research Programme's (WCRP's) Coupled Model Intercomparison Project phase 5 (CMIP5) multi-model dataset (http://cmip-pcmdi.llnl.gov/ cmip5/). The RCPs is the Representative Concentration Pathways, which describe a wide range of potential futures for the main drivers of climate change. The different value of "s" in the RCPs expresses different radiative forcing in 2100 (van Vuuren et al. 2011). The RCP26, RCP45 and RCP85 data during the period from 2011 to 2100 are selected in this paper. The RCP85 is a highly energy-intensive scenario as a result of high population growth, a lower rate of technology development and non-climate policy, which is representative of high scenarios in climate change. The RCP26, in contrast, is the representative of lowest scenarios in climate change, which requires stringent climate policies to limit global mean temperature within $2.0{ }^{\circ} \mathrm{C}$. For greenhouse gas emission, RCP26 has a peak around 2050, followed by a modest decline by the end of 
the century, while for RCP45, the intermediate scenarios, emissions are more or less stable throughout the century.

After comparatively analyzing relative interpolation methods, the mean annual biotemperature, average total annual precipitation and potential evapotranspiration ratio with $1 \mathrm{~km}$ resolution during all the four periods from 1981 to 2010, 2011 to 2040,2041 to 2070 , and 2071 to 2100 were respectively simulated by a high accuracy and speed method of surfacing modeling (HASM), which is described in detail by Yue (2010).

The spatial data of biome types in 2010, 2040, 2070 and 2100 were respectively generated by operating the Holdridge life zone (HLZ) model, in terms of the spatial data of mean annual biotemperature (MAB), average total annual precipitation (TAP), and potential evapotranspiration ratio (PER) simulated by HASM. The HLZ model (Holdridge $1947,1967,1971)$ is a scheme which utilizes the three bioclimatic variables to formulate the biome distribution (Yue et al. 2005, 2006). The HLZ model relates the distribution of major biome types (termed life zones) to bioclimatic variables, and has been widely accepted for use in projecting the impact of climate change on vegetation distribution (Post et al. 1982; Belotelov et al. 1996; Peng 2000, Yue et al. 2005, 2006, 2007, 2013; Fan et al. 2013b). The biome types distribution in China include nival area, alpine dry tundra, alpine moist tundra, alpine wet tundra, alpine rain tundra, boreal desert, boreal dry scrub, boreal moist forest, boreal wet forest, boreal rain forest, cool temperate desert, cool temperate scrub, cool temperate steppe, cool temperate moist forest, cool temperate wet forest, cool temperate rain forest, warm temperate desert, warm temperate desert scrub, warm temperate thorn steppe, warm temperate dry forest, warm temperate moist forest, warm temperate wet forest, subtropical dry forest, subtropical moist forest, subtropical wet forest, tropical desert and tropical moist forest.

Land cover data of karst areas of western China have been separated from the land cover data with $1 \mathrm{~km}$ resolution of the rest of China in 1980 and 2010. The classification of land cover in 1980 with an overall accuracy of $81 \%$ is derived from the Advanced Very High Resolution Radiometer (AVHRR) sensors (Liu et al. 2003). The classification of land cover in 2010 has an overall accuracy of $86 \%$ and is based on Landsat TM/ETM + images (Liu et al. 2014). The land cover types include evergreen coniferous forest, evergreen broadleaf forests, deciduous coniferous forest, deciduous broadleaf forest, mixed forest, scrublands, grassland, wetland, cropland, built land, nival area, desert and bare rock, and water area.

Scenario simulation of land cover

Land cover change is a complex process driven by interacting processes between multiple biophysical and socioeconomic factors. Because of the complexity of driving mechanism underlying land cover change, if all the relevant factors were taken into account in the procedure of land cover modeling, the model building would become extremely complex and fall into a dilemma. MAB, TAP and PER directly drive the change of vegetation distribution, and induce to the change of biome distribution on a landscape level. After comparing the correspondence of spatial distribution between biome types and land cover types, there are a very apparent similarity between the boundary of biome type and land cover type. Thusly, SMLCS were developed for simulating land cover scenarios in China (Fan 2005; Fan et al. 2005; Yue et al. 2007).

During the basic process of SMLCS development, the transition probability matrix between biomes and land cover types was created in terms of historical data of biome and land cover data. In this paper, a new transition probability matrix (TPM) (Table 1) is presented between each biome types and land cover types on the basis of the relative cover of each land cover type in every grid cell, e.g., a grid cell can contain $50 \%$ cropland, $30 \%$ forest land and 20 grassland, then the land cover data would consist of three probability data belong to three different kinds of land cover types respectively. Moreover, the suitable conversion restrictions were created to revise the irrationally conversion of land cover in terms of the policies of NNR and grain for green released by Chinese government (Fan et al. 2013c; Wen and Tang 2005). According to the TPM, land cover spatial pattern at a grid during next period should tend to that of biome type appeared at the grid during next period, e.g., at a grid $(x, y)$, if probability of land cover type $k$ corresponding to biome type occurred in $t+1$ period is more than that corresponding to biome type occurred in $t$ period, conversion probability of land cover type $k$ at the grid should increase. TPM and conversion restrictions can be formulated as:

$$
\begin{aligned}
& \begin{aligned}
\operatorname{LP}(x, y)_{k, t+1}= & \operatorname{LP}(x, y)_{k, t} \\
& \times \frac{1}{2}\left(1+\frac{\operatorname{HLZ}(x, y)_{k, t+1}-\operatorname{HLZ}(x, y)_{k, t}}{\operatorname{HLZ}(x, y)_{k, t+1}+\operatorname{HLZ}(x, y)_{k, t}}\right)
\end{aligned} \\
& \operatorname{LC}(x, y)_{t+1}=\operatorname{Value}(k)_{\max \left\{\operatorname{LP}(\mathrm{x}, \mathrm{y})_{\mathrm{k}, \mathrm{t}+1} \mid \mathrm{k}=1,2,3 \ldots . .13 ;\right\}} \\
& \text { if }\left\{\begin{array}{l}
\operatorname{LC}(x, y)_{t} \in \operatorname{NNR}, \operatorname{LC}(x, y)_{t+1} \neq(\operatorname{Lcrop}(x, y) \cup \operatorname{Lbuilt}(x, y)) \\
\operatorname{SLOPE}(x, y) \geq 25, \operatorname{LC}(x, y)_{t+1} \neq(\operatorname{Lcrop}(x, y))
\end{array}\right.
\end{aligned}
$$

$k=1,2,3 \ldots \ldots 13 ; t=2010,2040,2070,2100$

where $x, y$ is the coordinate of grid cell, $k$ is the type code of land cover, $t$ is the variable of time; $\operatorname{HLZP}(x, y)_{k, t}$ and $\operatorname{HLZP}(x, y)_{k, t+1}$ are respectively represent the transition 


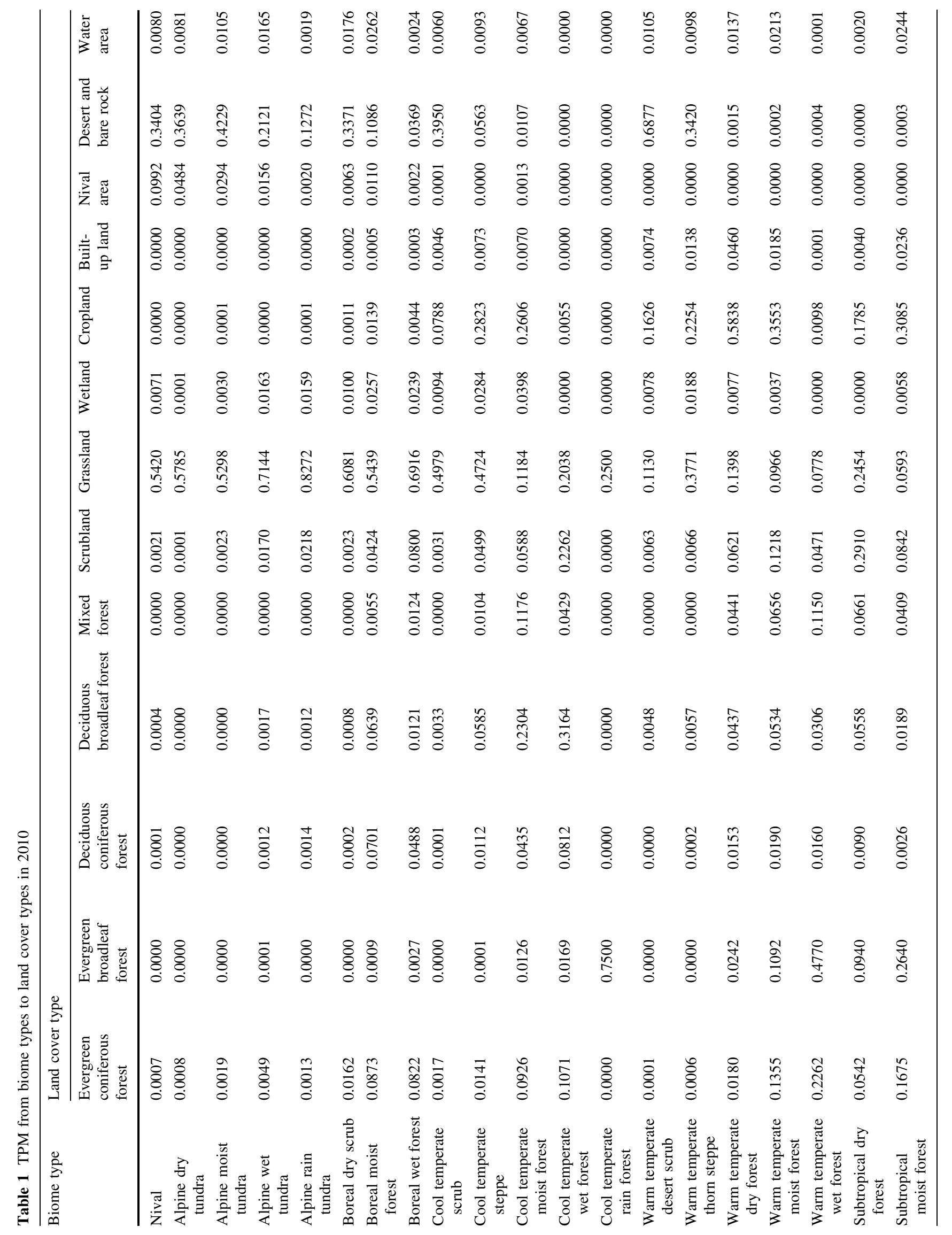


probability between land cover type $k$ and the biome type appeared at grid $(x, y)$ in $t$ and $t+1$ period; $\operatorname{LP}(x, y)_{k, t}$ is the percentage of land cover type $k$ contained in $\operatorname{grid}(x, y)$ which should satisfy the formula $\sum_{k=1}^{13} \operatorname{LP}(x, y)_{k, t}=1$; $\mathrm{LP}(x, y)_{k, t+1}$ is the transition probability of land cover type $k$ in $t+1$ period. $\operatorname{LC}(x, y)_{t}$ and $\operatorname{LC}(x, y)_{t+1}$ are respectively represent the types of land cover at $\operatorname{grid}(x, y)$ in $t$ and $t+1$ period; NNR is the boundary of NNR in China; $L \operatorname{crop}(x, y)$ represents the land cover type is cropland at grid $(x, y)$; Lbuilt $(x, y)$ represents the land cover type is built-up land at grid $(x, y)$; and $\operatorname{SLOPE}(x, y)$ is the slope value of the grid $(x, y)$. According to the policy of grain for green released by Chinese government, the land slope with over $25^{\circ}$ is restricted to use for cropland, and only for grass or forest (Wen and Tang 2005). So only the slope value of grid $(x, y)$ is $<25^{\circ}$ which can transform to cropland. Moreover, since the land of NNR is prohibited to use for cropland and builtup land (Fan et al. 2013c), the grid $(x, y)$ belongs to NNR which cannot transform to cropland and built-up land.

The simulation process of SMLCS includes the following major steps (Fig. 2): (1) obtaining the MAB, TAP and PER data with $1 \mathrm{~km}$ resolution of China by operating HASM; (2) simulating the biome distribution by running HLZ model; (3) establishing the TPM between each biome type and land cover type in terms of spatial data of biome and land cover in 2010; (4) identifying whether the biome type at grid $(x, y)$ will change or not from $t$ period to $t+1$ period; (5) evaluating the grid $(x, y)$ value of land cover type at $t+1$ period in terms of max value of transition probability and conversion restrictions; and (6) repeating steps 4 and 5 until all grid cells at $t+1$ period of land cover types are allocated.

\section{Validation of SMLCS}

During the process of validation, the land cover data in 1980 and the biome in 1980 and 2010 were used as the initial data. After operating SMLCS, we obtained the simulated land cover data in 2010. Then, we compared the simulated land cover data with actual land cover data in 2010 (Fig. 3). The assessment method of average total accuracy $\left(P_{\mathrm{ATA}}\right)$ and Kappa index $(\mathrm{KI})$ were used to validate the accuracy of SMLCS, which can be respectively formulated as,

$$
\begin{aligned}
& P_{\mathrm{ATA}}=\sum_{i=1}^{r} p_{i i} / N \\
& \mathrm{KI}=\left(N \sum_{i=1}^{r} p_{i i}-\sum_{i=1}^{r}\left(p_{i+} p_{+i}\right)\right) /\left(N^{2}-\sum_{i=1}^{r}\left(p_{i+} p_{+i}\right)\right)
\end{aligned}
$$


where $N$ is the total grid cell number of research area; $r$ is the number of land cover type; $p_{i i}$ is the grid cell number of $i$ th land cover type simulated correctly; $p_{i+}$ is the grid cell number of $i$ th type of actual land cover data; $p_{i+}$ is the grid cell number of $i$ th type of simulated land cover data. The validation indicates that the $\mathrm{P}_{A T A}$ and $\mathrm{KI}$ are respectively 90.25 and $87.96 \%$. Thusly, we can believe that SMLCS is suitable to simulate the land cover scenarios in other same periods.

\section{Results and analyses}

Spatial distribution of land cover types

According to the land cover scenarios based on RCP26, RCP45 and RCP85, there would be a very apparent similar variety on the spatial pattern of land cover scenarios in the karst areas of southwestern China from 2010 to 2100 (Fig. 4).

Evergreen coniferous forest and evergreen broadleaf forests would be mainly distributed in the mountainous and hilly regions of the Hengduan Mountains and around Sichuan Basin, Yunnan-Guizhou Plateau and the most part of hilly regions in Guangxi province. Other woodland types, including deciduous coniferous forest, deciduous broadleaf forest and mixed forest would be scattered in the south of Hengduan Mountains, Dabashan Mountains, Wushan Mountains, and Yunnan-Guizhou Plateau. Scrubland would mainly occur in the hilly region with relative low altitude of Yunnan, Guizhou and Guangxi. Grassland would be continuously and intensively distributed in the northwestern Sichuan Province. Besides, there would be grassland discontinuously distributed in Yunan, Guizhou and Guangxi Province, Staggered distribution with woodland in corresponding area.

Water area mainly includes rivers, lakes, reservoirs and water terraces distributed in southwestern China. From 2010 to 2100 , the main water body area is river areas, which include the upper reaches of Yangtze River, Mekong River and Zhujiang River within Yunnan, Guizhou, Sichuan, Chongqing and Guangxi provinces. Wetland would mainly occur in low-lying wet areas around lakes and watersheds. Nival areas include ice and snow land which would be mainly distributed in highly mountains of Western Sichuan province and Hengduan Mountains in northwestern of Yunan province. Desert and bare rock land mainly refer to karst rocky desertification area in southwestern China, especially distributed in the centered on Guizhou Plateau.

The distribution of built-up land in southwestern China is directly determined by the socioeconomic development, especially the speed of urban development, which is mainly distributed in the areas near rivers or valleys that have abundant water resources, fertile soil, convenient traffic, plentiful food and other living products. Cropland would be continuously and centrally distributed in Sichuan Basin, and extensively and discontinuously distributed in Yunnan-Guizhou Plateau and Guangxi province.

Area changes of land cover

During the period from 2010 to 2100 , the area of evergreen coniferous forest, wetland and water area would increase while the area of grassland, cropland, and desert and bare rock would decrease under all three scenarios of RCP26, RCP45 and RCP85 (Tables 2, 3, 4).

Under the RCP26 scenario: during all the three periods from 2010 to 2040,2040 to 2070 , and 2070 to 2100 , the decrease area of grassland would be the largest while desert and bare rock would have the maximum decrease rate; from 2010 to 2040, the area of evergreen coniferous forest would increase with the largest number and wetland would have the fastest increase rate; from 2040 to 2070, evergreen coniferous forest would have both the largest increase area and the fastest increase rate; from 2071 to 2100 , the area of mixed forest would increase with the largest number and wetland would have the fastest increase rate. During the third period from 2071 to 2100 , most land cover types would have the opposite change trends and change rate would become considerably smaller than the former two periods.

Under the RCP45 scenario: during the period from 2010 to 2040, the area of evergreen coniferous forest would increase with the largest number, wetland would have the fastest increase rate, the decrease area of grassland would have the maximum decrease area, and bare rock would have the fastest decrease rate. During all the three periods, the area of evergreen coniferous forest, evergreen broadleaf forest, scrubland, wetland and water areas would continuously increase, while the area of deciduous coniferous forest, deciduous broadleaf forest, grassland, cropland, and desert and bare rock would keep continual decrease trend.

Under the RCP85 scenario: during the period from 2010 to 2040, evergreen coniferous forest, wetland, grassland, and desert and bare rock would have the same change trend with the RCP26 and RCP45 scenario, which would respectively have the largest increase area, the fastest increase rate, the maximum decrease area and the fastest decrease rate; from 2041 to 2070, scrublands would have the largest increase area instead of evergreen coniferous forest, besides other change trends would be similar to those of the first period; from 2071 to 2100 , deciduous coniferous forest would have the greatest decrease rate instead of desert and bare rock, in addition other change trends would be similar to those of the second period. 
Fig. 2 Flowchart of key steps of SMLCS

Fig. 3 Actual land cover map (a) and simulated land cover map (b) in 2010
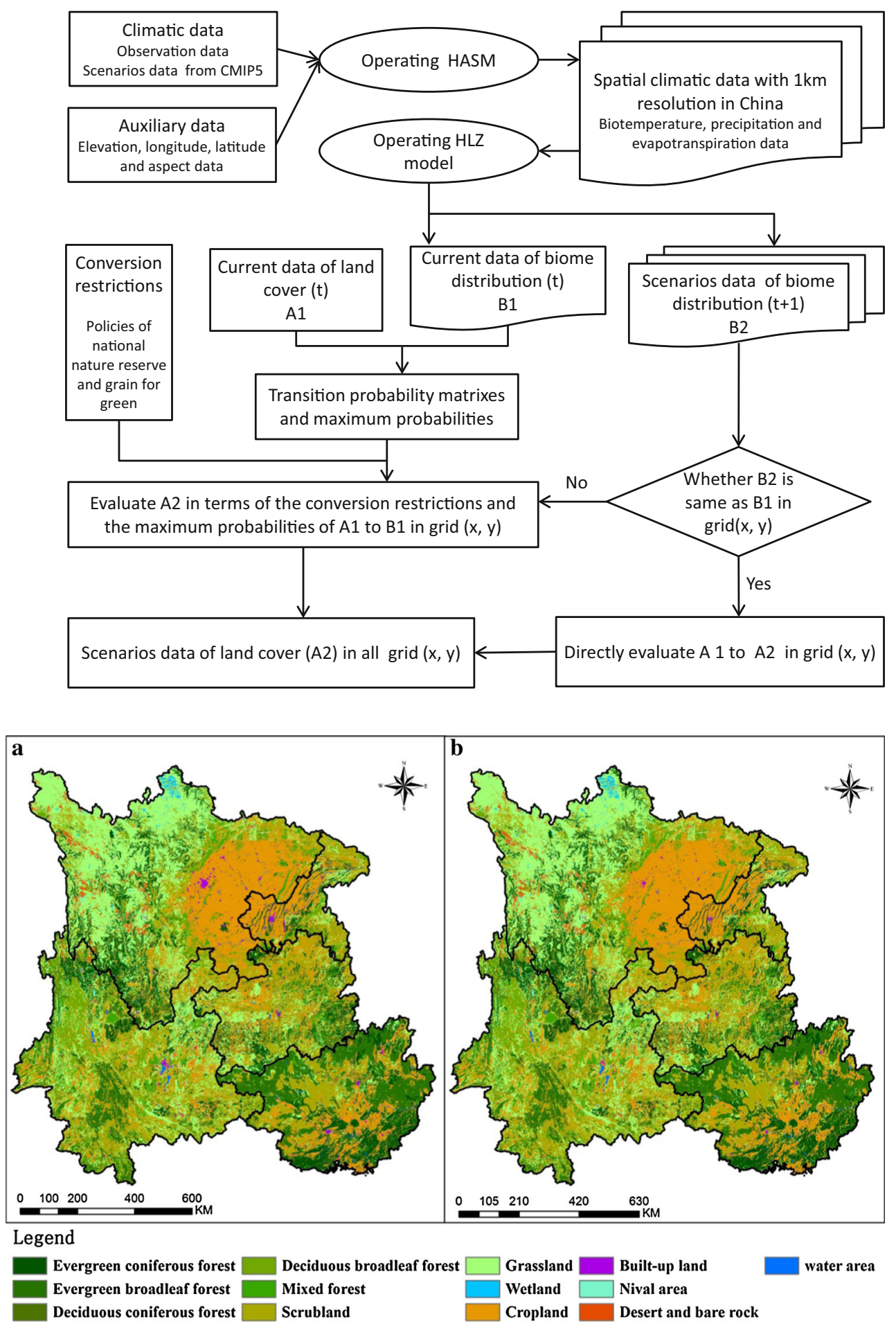

Spatial difference of land cover change in southwestern China

In terms of the three scenarios of RCP26, RCP45 and RCP85, most land cover types would have similar change trends during the period from 2010 to 2100. However, since the change of mean annual biotemperature (MAB) and average total annual precipitation (TAP) would occur spatial difference in southwestern China (Table 5), the change of land cover scenarios would have a different spatial pattern (Tables $6,7,8$ ).

The change of nival area, desert and bare rock would mainly occur in Yunnan and Sichuan under all the three scenarios, among which area would continually decrease in 


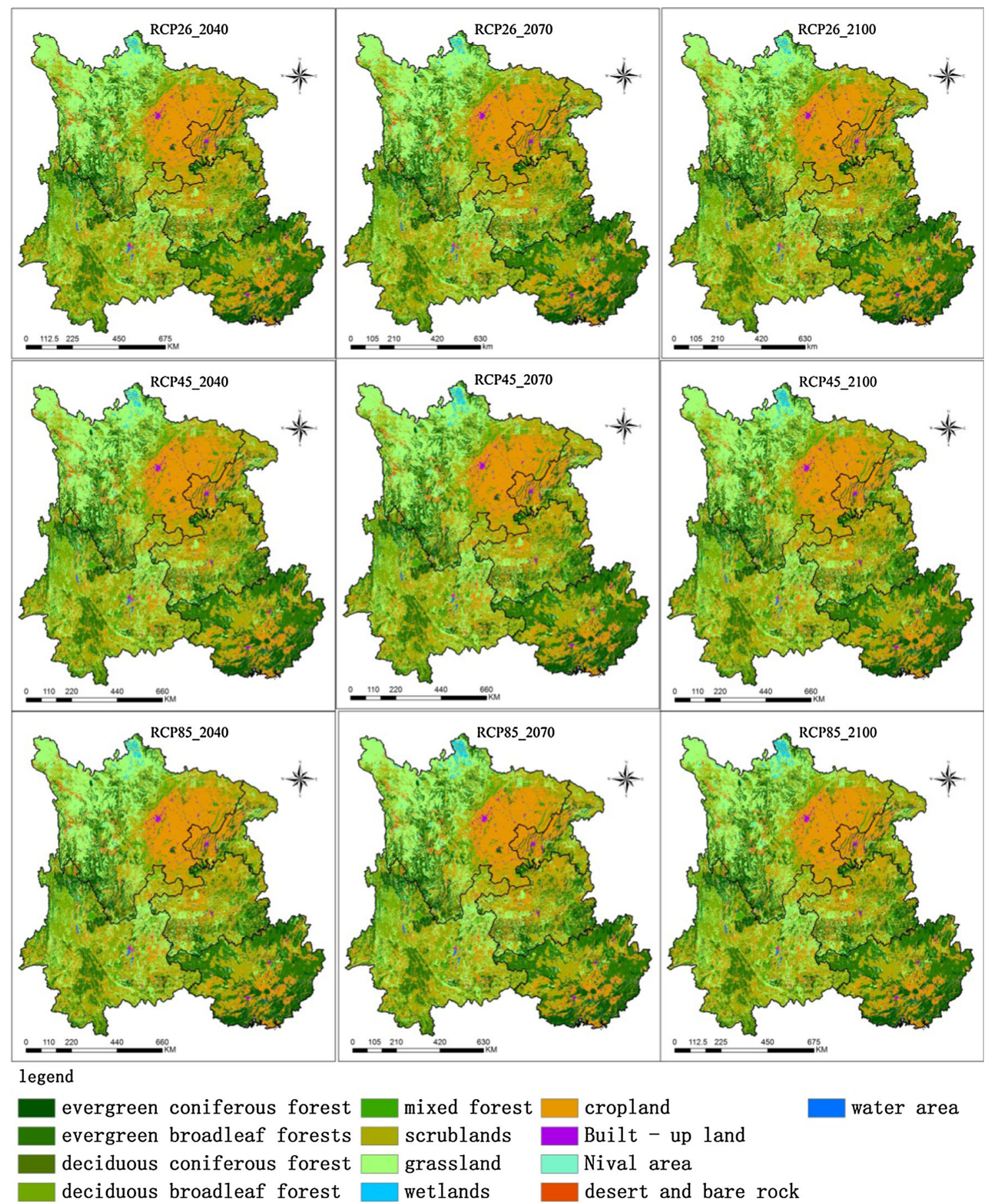

Fig. 4 Three scenarios of land cover in southwestern China

all the three scenarios except that nival area distributed in Sichuan would have a increase during the period from 2010 to 2040, and desert and bare rock distributed in Yunnan would increase during the period from 2070 to 2100 under RCP26 scenario. Grassland distributed in Sichuan, Guizhou and Guangxi would gradually decrease during all the three periods under all the three scenarios, but the annual decrement would be decelerating. Moreover, the change of grassland distributed in Chongqing and Yunnan would have a considerable fluctuation. The change of wetland would mainly occur in Sichuan, which would have a continuous increase trend during all the three periods under all the three scenarios. The area of evergreen broadleaf forest and evergreen coniferous forest would all continuously 
Table 2 Area change of land cover under RCP26 scenario (area unit: $\mathrm{km}^{2}$ )

\begin{tabular}{|c|c|c|c|c|c|c|c|c|}
\hline \multirow[t]{2}{*}{ Land cover type } & \multicolumn{2}{|l|}{2010} & \multicolumn{2}{|l|}{2040} & \multicolumn{2}{|l|}{2070} & \multicolumn{2}{|l|}{2100} \\
\hline & Area & $\begin{array}{l}\text { Rate } \\
(\%)\end{array}$ & $\begin{array}{l}\text { Change } \\
\text { area }\end{array}$ & $\begin{array}{l}\text { Change rate } \\
(\%)\end{array}$ & $\begin{array}{l}\text { Area } \\
\text { change }\end{array}$ & $\begin{array}{l}\text { Change rate } \\
(\%)\end{array}$ & $\begin{array}{l}\text { Area } \\
\text { change }\end{array}$ & $\begin{array}{l}\text { Change rate } \\
(\%)\end{array}$ \\
\hline $\begin{array}{l}\text { Evergreen coniferous } \\
\text { forest }\end{array}$ & 159,562 & 11.76 & 4333 & 2.72 & 3164 & 1.93 & 679 & 0.41 \\
\hline $\begin{array}{l}\text { Evergreen broadleaf } \\
\text { forests }\end{array}$ & 148,402 & 10.94 & 3374 & 2.27 & 2181 & 1.44 & -357 & -0.23 \\
\hline $\begin{array}{l}\text { Deciduous coniferous } \\
\text { forest }\end{array}$ & 12,936 & 0.95 & -410 & -3.17 & -541 & -4.32 & 9 & 0.08 \\
\hline $\begin{array}{l}\text { Deciduous broadleaf } \\
\text { forest }\end{array}$ & 58,360 & 4.30 & -996 & -1.71 & -826 & -1.44 & 450 & 0.80 \\
\hline Mixed forest & 55,864 & 4.12 & -670 & -1.20 & -27 & -0.05 & 1307 & 2.37 \\
\hline Scrubland & 248,586 & 18.32 & 3117 & 1.25 & 2288 & 0.91 & -59 & -0.02 \\
\hline Grassland & 321,990 & 23.73 & -6073 & -1.89 & -2911 & -0.92 & -2032 & -0.65 \\
\hline Wetland & 3844 & 0.28 & 336 & 8.74 & 14 & 0.33 & 259 & 6.18 \\
\hline Cropland & 319,196 & 23.52 & -2012 & -0.63 & -2420 & -0.76 & -371 & -0.12 \\
\hline Built-up land & 8019 & 0.59 & 132 & 1.65 & -37 & -0.45 & 77 & 0.95 \\
\hline Nival area & 890 & 0.07 & -15 & -1.69 & -17 & -1.94 & 15 & 1.75 \\
\hline Desert and bare rock & 13,614 & 1.00 & -1177 & -8.65 & -973 & -7.82 & -83 & -0.72 \\
\hline Water area & 5821 & 0.43 & 61 & 1.05 & 105 & 1.79 & 106 & 1.77 \\
\hline
\end{tabular}

Table 3 Area change of land cover under RCP45 scenario (area unit: $\mathrm{km}^{2}$ )

\begin{tabular}{|c|c|c|c|c|c|c|c|c|}
\hline \multirow[t]{2}{*}{ Land cover type } & \multicolumn{2}{|l|}{2010} & \multicolumn{2}{|l|}{2040} & \multicolumn{2}{|l|}{2070} & \multicolumn{2}{|l|}{2100} \\
\hline & Area & $\begin{array}{l}\text { Rate } \\
(\%)\end{array}$ & $\begin{array}{l}\text { Change } \\
\text { area }\end{array}$ & $\begin{array}{l}\text { Change rate } \\
(\%)\end{array}$ & $\begin{array}{l}\text { Area } \\
\text { change }\end{array}$ & $\begin{array}{l}\text { Change rate } \\
(\%)\end{array}$ & $\begin{array}{l}\text { Area } \\
\text { change }\end{array}$ & $\begin{array}{l}\text { Change rate } \\
(\%)\end{array}$ \\
\hline $\begin{array}{l}\text { Evergreen coniferous } \\
\text { forest }\end{array}$ & 159,562 & 11.76 & 3804 & 2.38 & 5638 & 3.45 & 2358 & 1.4 \\
\hline $\begin{array}{l}\text { Evergreen broadleaf } \\
\text { forests }\end{array}$ & 148,402 & 10.94 & 2918 & 1.97 & 4091 & 2.7 & 1347 & 0.87 \\
\hline $\begin{array}{l}\text { Deciduous coniferous } \\
\text { forest }\end{array}$ & 12,936 & 0.95 & -306 & -2.37 & -1075 & -8.51 & -468 & -4.05 \\
\hline $\begin{array}{l}\text { Deciduous broadleaf } \\
\text { forest }\end{array}$ & 58,360 & 4.3 & -316 & -0.54 & -1004 & -1.73 & -541 & -0.95 \\
\hline Mixed forest & 55,864 & 4.12 & -547 & -0.98 & -779 & -1.41 & 355 & 0.65 \\
\hline Scrubland & 248,586 & 18.32 & 2685 & 1.08 & 5343 & 2.13 & 1968 & 0.77 \\
\hline Grassland & 321,990 & 23.73 & -6749 & -2.1 & -7783 & -2.47 & -3470 & -1.13 \\
\hline Wetland & 3844 & 0.28 & 814 & 21.18 & 1220 & 26.19 & 268 & 4.56 \\
\hline Cropland & 319,196 & 23.52 & -1775 & -0.56 & -3884 & -1.22 & -1387 & -0.44 \\
\hline Built-up land & 8019 & 0.59 & 180 & 2.24 & -72 & -0.88 & 26 & 0.32 \\
\hline Nival area & 890 & 0.07 & 4 & 0.45 & -31 & -3.47 & -20 & -2.32 \\
\hline Desert and bare rock & 13,614 & 1 & -825 & -6.06 & -1862 & -14.56 & -576 & -5.27 \\
\hline Water area & 5821 & 0.43 & 113 & 1.94 & 198 & 3.34 & 140 & 2.28 \\
\hline
\end{tabular}

increase in the five provinces of southwestern China during all the three periods under the RCP45 and RCP85 scenarios, except that evergreen coniferous forest distributed in Yunnan would decrease in the period from 2010 to 2040. In terms of all the three scenarios, the cropland area of the five provinces in southwestern China would have a continuous decrease trend during all the three periods, among which the main decrement would come from Yunnan and 
Table 4 Area change of land cover under RCP85 scenario (area unit: $\mathrm{km}^{2}$ )

\begin{tabular}{|c|c|c|c|c|c|c|c|c|}
\hline \multirow[t]{2}{*}{ Land cover type } & \multicolumn{2}{|l|}{2010} & \multicolumn{2}{|l|}{2040} & \multicolumn{2}{|l|}{2070} & \multicolumn{2}{|l|}{2100} \\
\hline & Area & $\begin{array}{l}\text { Rate } \\
(\%)\end{array}$ & $\begin{array}{l}\text { Change } \\
\text { area }\end{array}$ & $\begin{array}{l}\text { Change rate } \\
(\%)\end{array}$ & $\begin{array}{l}\text { Area } \\
\text { change }\end{array}$ & $\begin{array}{l}\text { Change rate } \\
(\%)\end{array}$ & $\begin{array}{l}\text { Area } \\
\text { change }\end{array}$ & $\begin{array}{l}\text { Change rate } \\
(\%)\end{array}$ \\
\hline $\begin{array}{l}\text { Evergreen coniferous } \\
\text { forest }\end{array}$ & 159,562 & 11.76 & 3880 & 2.43 & 5924 & 3.62 & 4483 & 2.65 \\
\hline $\begin{array}{l}\text { Evergreen broadleaf } \\
\text { forests }\end{array}$ & 148,402 & 10.94 & 3105 & 2.09 & 5323 & 3.51 & 2503 & 1.6 \\
\hline $\begin{array}{l}\text { Deciduous coniferous } \\
\text { forest }\end{array}$ & 12,936 & 0.95 & -306 & -2.37 & -1280 & -10.13 & -1330 & -11.72 \\
\hline $\begin{array}{l}\text { Deciduous broadleaf } \\
\text { forest }\end{array}$ & 58,360 & 4.3 & -225 & -0.39 & -964 & -1.66 & -203 & -0.36 \\
\hline Mixed forest & 55,864 & 4.12 & -1069 & -1.91 & -2357 & -4.3 & -1720 & -3.28 \\
\hline Scrubland & 248,586 & 18.32 & 2520 & 1.01 & 9617 & 3.83 & 7222 & 2.77 \\
\hline Grassland & 321,990 & 23.73 & -6736 & -2.09 & -9107 & -2.89 & -5876 & -1.92 \\
\hline Wetland & 3844 & 0.28 & 1014 & 26.38 & 1963 & 40.41 & 209 & 3.06 \\
\hline Cropland & 319,196 & 23.52 & -1526 & -0.48 & -6924 & -2.18 & -4371 & -1.41 \\
\hline Built-up land & 8019 & 0.59 & 161 & 2.01 & -159 & -1.94 & 69 & 0.86 \\
\hline Nival area & 890 & 0.07 & 1 & 0.11 & -34 & -3.82 & -60 & -7 \\
\hline Desert and bare rock & 13,614 & 1 & -889 & -6.53 & -2190 & -17.21 & -996 & -9.45 \\
\hline Water area & 5821 & 0.43 & 70 & 1.2 & 188 & 3.19 & 70 & 1.15 \\
\hline
\end{tabular}

Table 5 Scenarios of MAB and TAP in the five provinces of southwestern China

\begin{tabular}{|c|c|c|c|c|c|c|c|c|c|}
\hline \multirow[t]{2}{*}{ Scenario } & \multirow[t]{2}{*}{ Region } & \multicolumn{2}{|c|}{ From 1980 to 2010} & \multicolumn{2}{|c|}{ From 2011 to 2040} & \multicolumn{2}{|c|}{ From 2041 to 2070} & \multicolumn{2}{|c|}{ From 2071 to 2100} \\
\hline & & MAB & TAP & MAB & TAP & MAB & TAP & MAB & TAP \\
\hline \multirow[t]{6}{*}{ RCP26 } & Sichuan & 9.17 & 790.63 & 9.89 & 811.35 & 10.23 & 859.54 & 10.18 & 862.24 \\
\hline & Chongqing & 15.82 & 1109.51 & 16.64 & 1092.68 & 17.17 & 1135.49 & 17.11 & 1150.46 \\
\hline & Yunnan & 15.53 & 1051.25 & 16.36 & 1051.62 & 16.74 & 1098.29 & 16.72 & 1080.23 \\
\hline & Guizhou & 15.16 & 1131.43 & 16.21 & 1126.88 & 16.69 & 1157.84 & 16.64 & 1175.71 \\
\hline & Guangxi & 20.10 & 1518.81 & 20.94 & 1520.21 & 21.39 & 1546.44 & 21.36 & 1534.70 \\
\hline & Southwestern China & 14.03 & 1053.39 & 14.85 & 1059.47 & 15.25 & 1100.88 & 15.21 & 1097.95 \\
\hline \multirow[t]{6}{*}{ RCP45 } & Sichuan & 9.17 & 790.63 & 9.93 & 797.19 & 10.64 & 860.24 & 10.98 & 898.53 \\
\hline & Chongqing & 15.82 & 1109.51 & 16.65 & 1091.11 & 17.62 & 1128.30 & 18.03 & 1166.57 \\
\hline & Yunnan & 15.53 & 1051.25 & 16.45 & 1027.20 & 17.25 & 1090.97 & 17.67 & 1117.87 \\
\hline & Guizhou & 15.16 & 1131.43 & 16.25 & 1123.68 & 17.14 & 1168.00 & 17.57 & 1198.54 \\
\hline & Guangxi & 20.10 & 1518.81 & 20.98 & 1512.26 & 21.84 & 1553.98 & 22.25 & 1571.30 \\
\hline & Southwestern China & 14.03 & 1053.39 & 14.90 & 1045.68 & 15.70 & 1101.25 & 16.09 & 1131.71 \\
\hline \multirow[t]{6}{*}{ RCP85 } & Sichuan & 9.17 & 790.63 & 10.00 & 793.15 & 11.20 & 865.24 & 12.64 & 938.31 \\
\hline & Chongqing & 15.82 & 1109.51 & 16.77 & 1076.54 & 18.33 & 1118.06 & 20.04 & 1159.06 \\
\hline & Yunnan & 15.53 & 1051.25 & 16.50 & 1024.97 & 17.85 & 1096.32 & 19.41 & 1173.36 \\
\hline & Guizhou & 15.16 & 1131.43 & 16.33 & 1110.67 & 17.80 & 1147.03 & 19.42 & 1198.55 \\
\hline & Guangxi & 20.10 & 1518.81 & 21.06 & 1494.99 & 22.47 & 1529.42 & 23.86 & 1557.77 \\
\hline & Southwestern China & 14.03 & 1053.39 & 14.97 & 1038.06 & 16.31 & 1096.95 & 17.81 & 1158.66 \\
\hline
\end{tabular}

Sichuan. The area of built-up land in whole southwestern China would have a continuous increase trend during all the three periods under the three scenarios except a decrease in Yunnan province.

\section{Discussion and conclusions}

During the period from 2010 to 2100 , the results of land cover scenarios under RCP26, RCP45 and RCP85 indicate 
Table 6 Difference of land cover change in the five provinces of southwestern China under RCP26 scenario (Unit: $\left.\mathrm{km}^{2}\right)$

\begin{tabular}{|c|c|c|c|c|c|c|c|c|c|c|c|c|c|c|c|}
\hline \multirow[t]{2}{*}{ Land cover type } & \multicolumn{3}{|c|}{ Sichuan } & \multicolumn{3}{|c|}{ Chongqing } & \multicolumn{3}{|c|}{ Guizhou } & \multicolumn{3}{|c|}{ Guangxi } & \multicolumn{3}{|l|}{ Yunnan } \\
\hline & $\mathrm{T} 1$ & $\mathrm{~T} 2$ & $\mathrm{~T} 3$ & $\mathrm{~T} 1$ & $\mathrm{~T} 2$ & $\mathrm{~T} 3$ & $\mathrm{~T} 1$ & $\mathrm{~T} 2$ & $\mathrm{~T} 3$ & $\mathrm{~T} 1$ & $\mathrm{~T} 2$ & $\mathrm{~T} 3$ & $\mathrm{~T} 1$ & $\mathrm{~T} 2$ & $\mathrm{~T} 3$ \\
\hline $\begin{array}{l}\text { Evergreen coniferous } \\
\text { forest }\end{array}$ & 3148 & 1452 & 535 & 535 & 372 & -41 & 1112 & 617 & -46 & 76 & 18 & 0 & -538 & 705 & 231 \\
\hline $\begin{array}{l}\text { Evergreen broadleaf } \\
\text { forests }\end{array}$ & 523 & 168 & -59 & 16 & 14 & -3 & 1279 & 1022 & -132 & 193 & 49 & -4 & 1363 & 928 & -159 \\
\hline $\begin{array}{l}\text { Deciduous coniferous } \\
\text { forest }\end{array}$ & -32 & -283 & -74 & -1 & -1 & 1 & -261 & -174 & 19 & -1 & 0 & 0 & -115 & -83 & 63 \\
\hline $\begin{array}{l}\text { Deciduous broadleaf } \\
\text { forest }\end{array}$ & 117 & -275 & 189 & -173 & -75 & 10 & -22 & -15 & 1 & -2 & 0 & 0 & -916 & -461 & 250 \\
\hline Mixed forest & 402 & 331 & 673 & -127 & -2 & -3 & -347 & -322 & 55 & -2 & 0 & 0 & -596 & -34 & 582 \\
\hline Scrubland & 3042 & 1967 & 253 & -360 & -1 & 0 & -368 & -475 & 106 & -17 & 0 & 0 & 820 & 797 & -418 \\
\hline Grassland & -6502 & -1421 & -1078 & 19 & -112 & 7 & -677 & -409 & 6 & -202 & -65 & 4 & 1289 & -904 & -971 \\
\hline Wetland & 322 & 10 & 256 & 0 & 0 & 0 & -2 & 0 & 0 & 0 & 0 & 0 & 16 & 4 & 3 \\
\hline Cropland & -239 & -1152 & -672 & 77 & -221 & 29 & -756 & -273 & 2 & -45 & -2 & 0 & -1049 & -772 & 270 \\
\hline Built-up land & 184 & 46 & 14 & 4 & 25 & 0 & 22 & 21 & -10 & 0 & 0 & 0 & -78 & -129 & 73 \\
\hline Nival area & -7 & -14 & 14 & 0 & 0 & 0 & 0 & 0 & 0 & 0 & 0 & 0 & -8 & -3 & 1 \\
\hline Desert and bare rock & -1047 & -908 & -90 & 0 & 0 & 0 & 1 & 0 & 0 & 0 & 0 & 0 & -131 & -65 & 7 \\
\hline Water area & 89 & 79 & 39 & 10 & 1 & 0 & 19 & 8 & -1 & 0 & 0 & 0 & -57 & 17 & 68 \\
\hline
\end{tabular}

Table 7 Difference of land cover change in the five provinces of southwestern China under RCP45 scenario (Unit: $\left.\mathrm{km}^{2}\right)$

\begin{tabular}{|c|c|c|c|c|c|c|c|c|c|c|c|c|c|c|c|}
\hline \multirow[t]{2}{*}{ Land cover type } & \multicolumn{3}{|l|}{ Sichuan } & \multicolumn{3}{|c|}{ Chongqing } & \multicolumn{3}{|c|}{ Guizhou } & \multicolumn{3}{|c|}{ Guangxi } & \multicolumn{3}{|l|}{ Yunnan } \\
\hline & $\mathrm{T} 1$ & $\mathrm{~T} 2$ & T3 & $\mathrm{T} 1$ & $\mathrm{~T} 2$ & $\mathrm{~T} 3$ & $\mathrm{~T} 1$ & $\mathrm{~T} 2$ & T3 & $\mathrm{T} 1$ & $\mathrm{~T} 2$ & $\mathrm{~T} 3$ & $\mathrm{~T} 1$ & $\mathrm{~T} 2$ & T3 \\
\hline $\begin{array}{l}\text { Evergreen } \\
\text { coniferous } \\
\text { forest }\end{array}$ & 3453 & 2720 & 1085 & 539 & 581 & 126 & 1049 & 1139 & 383 & 77 & 29 & 2 & -1314 & 1169 & 762 \\
\hline $\begin{array}{l}\text { Evergreen } \\
\text { broadleaf } \\
\text { forests }\end{array}$ & 428 & 351 & 121 & 17 & 25 & 12 & 1351 & 1941 & 593 & 199 & 80 & 23 & 923 & 1694 & 598 \\
\hline $\begin{array}{l}\text { Deciduous } \\
\text { coniferous } \\
\text { forest }\end{array}$ & -32 & -510 & $-226-$ & 0 & -3 & 0 & -216 & -397 & -174 & -1 & 0 & 0 & -57 & -165 & -68 \\
\hline $\begin{array}{l}\text { Deciduous } \\
\text { broadleaf } \\
\text { forest }\end{array}$ & 645 & -94 & -7 & -175 & -128 & -70 & -26 & -14 & -6 & -2 & 0 & 0 & -758 & -768 & -458 \\
\hline Mixed forest & 512 & 100 & 695 & -132 & v30 & -14 & -381 & -582 & -123 & -2 & 0 & 0 & -544 & -267 & -203 \\
\hline Scrubland & 2893 & 4624 & 1567 & -444 & -133 & 89 & -518 & -950 & -308 & -17 & 0 & 0 & 771 & 1802 & 620 \\
\hline Grassland & -8290 & -5000 & -2261 & 22 & -148 & -42 & -600 & -773 & -309 & -209 & -106 & -25 & 2328 & -1756 & -833 \\
\hline Wetland & 801 & 1215 & 267 & 0 & 0 & 0 & -2 & 0 & 0 & 0 & 0 & 0 & 15 & 5 & 1 \\
\hline Cropland & -50 & -1826 & -809 & 147 & -178 & -102 & -701 & -451 & -88 & -45 & -3 & 0 & -1126 & -1426 & -388 \\
\hline Built-up land & 208 & 52 & 20 & 16 & 13 & -1 & 22 & 64 & 22 & 0 & 0 & 0 & -66 & -201 & -15 \\
\hline Nival area & 11 & -27 & -15 & 0 & 0 & 0 & 0 & 0 & 0 & 0 & 0 & 0 & -7 & -4 & -5 \\
\hline $\begin{array}{l}\text { Desert and bare } \\
\text { rock }\end{array}$ & -700 & -1745 & -528 & 0 & 0 & 0 & 1 & 0 & 0 & 0 & 0 & 0 & -126 & -117 & -48 \\
\hline Water area & 121 & 140 & 91 & 10 & 1 & 2 & 21 & 23 & 10 & 0 & 0 & 0 & -39 & 34 & 37 \\
\hline
\end{tabular}

that deciduous coniferous forest, deciduous broadleaf forest, grassland, cropland, nival area, and desert and bare rock would have a gradual decrease trend, while evergreen coniferous forest, evergreen broadleaf forests, mixed forest, scrubland, wetland, built-up land and water body would gradually increase. Wetland would increase with the fastest rate (increasing $5.28 \%$ per decade on average), and builtup land would have the slowest increase rate (only 
Table 8 Difference of land cover change in the five provinces of southwestern China under RCP85 scenario (Unit: $\left.\mathrm{km}^{2}\right)$

\begin{tabular}{|c|c|c|c|c|c|c|c|c|c|c|c|c|c|c|c|}
\hline \multirow[t]{2}{*}{ Land cover type } & \multicolumn{3}{|c|}{ Sichuan } & \multicolumn{3}{|c|}{ Chongqing } & \multicolumn{3}{|c|}{ Guizhou } & \multicolumn{3}{|c|}{ Guangxi } & \multicolumn{3}{|c|}{ Yunnan } \\
\hline & $\mathrm{T} 1$ & $\mathrm{~T} 2$ & $\mathrm{~T} 3$ & $\mathrm{~T} 1$ & $\mathrm{~T} 2$ & $\mathrm{~T} 3$ & $\mathrm{~T} 1$ & $\mathrm{~T} 2$ & $\mathrm{~T} 3$ & $\mathrm{~T} 1$ & $\mathrm{~T} 2$ & $\mathrm{~T} 3$ & $\mathrm{~T} 1$ & $\mathrm{~T} 2$ & $\mathrm{~T} 3$ \\
\hline $\begin{array}{l}\text { Evergreen coniferous } \\
\text { forest }\end{array}$ & 3619 & 3165 & 2350 & 599 & 653 & 60 & 1003 & 1332 & 491 & 79 & 32 & 12 & -1420 & 742 & 1570 \\
\hline $\begin{array}{l}\text { Evergreen broadleaf } \\
\text { forests }\end{array}$ & 439 & 479 & 412 & 19 & 40 & 32 & 1455 & 2683 & 742 & 203 & 104 & 15 & 989 & 2017 & 1302 \\
\hline $\begin{array}{l}\text { Deciduous coniferous } \\
\text { forest }\end{array}$ & -31 & -549 & -649 & 0 & -2 & -3 & -197 & -522 & -360 & -1 & 0 & 0 & -77 & -207 & -318 \\
\hline $\begin{array}{l}\text { Deciduous broadleaf } \\
\text { forest }\end{array}$ & 658 & 480 & 798 & -189 & -169 & 11 & -28 & -19 & -22 & -2 & 0 & 0 & -664 & -1256 & -990 \\
\hline Mixed forest & 139 & -372 & -1041 & -139 & -66 & -62 & -416 & -724 & -75 & -2 & -1 & 0 & -651 & -1194 & -542 \\
\hline Scrubland & 2899 & 7998 & 5956 & -538 & -32 & 719 & -734 & -1583 & -189 & -17 & 0 & 0 & 910 & 3234 & 736 \\
\hline Grassland & -8613 & -7813 & -4826 & 15 & -94 & 202 & -505 & -907 & -363 & -215 & -132 & -27 & 2582 & -161 & -862 \\
\hline Wetland & 1006 & 1963 & 221 & 0 & 0 & 0 & -2 & 0 & 0 & 0 & 0 & 0 & 10 & 0 & -12 \\
\hline Cropland & 309 & -3494 & -2282 & 205 & -344 & -960 & -622 & -387 & -239 & -45 & -3 & 0 & -1373 & -2696 & -890 \\
\hline Built-up land & 206 & 43 & 15 & 18 & 11 & 1 & 25 & 94 & 10 & 0 & 0 & 0 & -88 & -307 & 43 \\
\hline Nival area & 9 & -26 & -36 & 0 & 0 & 0 & 0 & 0 & 0 & 0 & 0 & 0 & -8 & -8 & -24 \\
\hline Desert and bare rock & -738 & -2030 & -949 & 0 & 0 & 0 & 1 & 0 & 1 & 0 & 0 & 0 & -152 & -160 & -48 \\
\hline Water area & 98 & 156 & 31 & 10 & 3 & 0 & 20 & 33 & 4 & 0 & 0 & 0 & -58 & -4 & 35 \\
\hline
\end{tabular}

increasing $0.16 \%$ per decade on average). The area of desert and bare rock would decrease with the fastest rate (decreasing $2.34 \%$ per decade on average), and cropland would have the slowest decrease rate(just decreasing $0.26 \%$ per decade on average). It is worth noting that the change of land cover scenarios would have different change rate under different climate scenarios. In general, the land cover change under RCP85 scenario would have the fastest change rate, especially, nival area decreasing far more than the other two scenarios, and the change rate of land cover under RCP26 scenario would have the slowest change rate. Moreover, the area of every land cover type would generally keep the similar change direction during the period from 2010 to 2100 under all the three scenarios except that the opposite change direction would be occurred during the period from 2070 to 2100 under RCP26 scenario. The accuracy validation and the results of land cover scenarios simulated by operating the improved SMLC indicate that SMLCS, as a stochastic model of land cover change, is suitable to simulate the land cover scenarios on a regional scale, through combining with HASM method and HLZ model. On the basis of the current land cover data, observation historic climatic data, simulated climatic scenarios data, and DEM data, SMLCS can be not only use to simulate land cover in the future, but also to retrieve the land cover change in the past. Moreover, SMLCS focuses primarily on simulating the general trend of land cover scenarios driven by climate change in a landscape level, the accuracy of which is directly effected by the TPM between biome types and land cover types. HLZ model can be use to effectively simulate the biome types in the long term (decades to centuries) (Herrick et al. 2006; Lugo et al.
1999), so we think that SMLCS can be use to simulate the land cover scenarios in the time scale of every 30 years.

The improved SMLCS was be considered the policies of NNR and grain for green released by Chinese government more the former version of SMLCS (Fan 2005; Yue et al. 2007), but it is still need to consider more parameter data such as farming format, resident lifestyle, population density and government policy, etc. In our future work on SMLCS, we will focus on analyzing and discussing the driving factors which will lead to the land cover change included urban extension, road construction, population increase, and economic development on different spatial and time scales.

Acknowledgments This work is supported by the Program of National Natural Science Foundation of China (Nos. 41271406 and 91325204), National High-tech R\&D Program of the Ministry of Science and Technology of the People's Republic of China (No. 2013AA122003), and the Key Program of National Natural Science of China (No. 41023010). We would like to acknowledge the two anonymous reviewers for their valuable comments and suggestions.

\section{References}

Arnell NW, Livermore MJL, Kovats S, Levy PE, Nicholls R, Parry ML, Gaffin SR (2004) Climate and socio-economic scenarios for global-scale climate change impacts assessments: characterising the SRES storylines. Global Environ Chang 14:3-20

Belotelov NV, Bogatyrev BG, Kirilenko AP, Venevsky SV (1996) Modelling of time-dependent biomes shifts under global climate changes. Ecol Model 87:29-40

Cai YL (1999) Ecological rehabilitation and development of agriculture, forestry and animal husbandry in karst mountain areas of southwest China: status quo and trend of study. Resour Sci 21(5):37-41 (In Chinese) 
Chapin FS III, Zavaleta ES, Eviner VT et al (2000) Consequences of changing biodiversity. Nat 405:234-242

Fan ZM (2005) Design and application of Resources and environment model-base system: spatial trend and scenarios modeling of terrestrial ecosystems in China. Doctoral Thesis. Institute of Geographical and Natural Resources Research, CAS (In Chinese)

Fan ZM, Yue TX, Liu JY, Ma SN (2005) Patial and temporal distribution of land cover scenarios in China. Acta Geograp Sin 60(6):941-952 (In Chinese)

Fan ZM, Li J, Yue TX (2013a) Land-cover changes of biome transition zones in Loess Plateau of China. Ecol Model 252:129-140

Fan ZM, Li J, Yue TX (2013b) Spatial-temporal change of land-cover in ecosystem transitional zones on Loess Plateau of China. J Nat Res 28(3):426-436 (In Chinese)

Fan ZM, Zhang X, Li J, Yue TX, Liu JY, Xiang B, Kuang WH (2013c) Land-cover changes of national nature reserves in China. J Geogr Sci 23(2):258-270

Foley JA, DeFries R, Asner GP et al (2005) Global consequences of land use. Science 309:570-574

Guo F, Jiang GH, Yuan DX, Polk JS (2013) Evolution of major environmental geological problems in karst areas of Southwestern China. Environ Earth Sci 69:2427-2435

Herrick JE, Bestelmeyer BT, Archerb S, Tugelc AJ, Brown JR (2006) An integrated framework for science-based arid land management. J Arid Environ 65: 319-335

Hochstrasser T, Kröel-Dulay G, Peters D, Gosz J (2002) Vegetation and climate characteristics of arid and semi-arid grasslands in North America and their biome transition zone. J Arid Environ 51:55-78

Holdridge LR (1947) Determination of world plant formations from simple climate data. Sci 105:367-368

Holdridge LR (1967) Life zone ecology. Tropical Science Center. San Jose, Costa Rica

Holdridge LR, Grenke WC, Hatheway WH, Liang T, Tosi JA (1971) Forest Environments in Tropical Life Zones. Pergamon Press, Oxford

Huang QH, Cai YL (2007) Spatial pattern of karst rock desertification in the Middle of Guizhou Province. Southwestern China. Environ Geol 52(7):1325-1330

Hubacek K, Sun LX (2001) A scenario analysis of China's land use and land cover change: incorporating biophysical information into input-output modeling. Struct Chang Econ Dynam 12:367-397

Li S, Wang JH, Wang XZ, Li HX, Chen ZJ, Liao XX (2009a) A study of rock desertification processes and their driving forces in northern part of Guangdong, China, from 1974 to 2004-a case study on four counties of Yingde, Yangshan, Ruyuan and Lianzhou. J Nat Resour 24(5):816-826

Li YB, Shao JG, Yang H, Bai XY (2009b) The relations between land use and karst rocky desertification in a typical karst area. China Environ Geol 57(3):621-627

Li YB, Shao JG, Yang H, Bai XY (2009c) The relations between land use and karst rocky desertification in a typical karst area, China. Environ Geomor 57(3):621-627

Li J, Fan ZM, Yue TX (2014) Spatio-temporal simulation of land cover scenarios in southwestern of China. Acta Ecol Sin 34(12):3266-3275 (In Chinese)

Liu JY, Zhuang DF, Luo D, Xiao XM (2003) Land cover classification of China: integrated analysis of AVHRR imagery and geophysical data. Int J Remote Sens 24(12):2485-2500

Liu YS, Wang JY, Deng XZ (2008) Rocky land desertification and its driving forces in the karst areas of rural Guangxi, Southwest China. J Mt Sci 5(4):350-357

Liu JY, Kuang WH, Zhang ZX et al (2014) Spatiotemporal characteristics, patterns, and causes of land-use changes in China since the late 1980s. J Geogr Sci 24(2):195-210
Lugo AE, Brown SL, Dodson R, Smith TS, Shugart HH (1999) The Holdridge life zones of the conterminous United States in relation to ecosystem mapping. J Biogeogr 26:1025-1038

Marke T, Strasser U, Kraller G, Warscher M, Kunstmann H, Franz H, Vogel M (2013) The Berchtesgaden National Park (Bavaria, Germany): a platform for interdisciplinary catchment research. Environ Earth Sci 69:679-694

Niehoff D, Fritsch U, Bronstert A (2002) Land-use impacts on stormrunoff generation: scenarios of land-use change and simulation of hydrological response in a meso-scale catchment in SWGermany. J Hydrol 267:80-93

Peng CH (2000) From static biogeographical model to dynamic global vegetation model: a global perspective on modeling vegetation dynamics. Ecol Model 135:33-54

Peng J, Xu YC, Cai YL, Xiao HL (2011) Climatic and anthropogenic drivers of land use/cover change in fragile karst areas of southwest China since the early 1970s: a case study on the Maotiaohe watershed. Environ Earth Sci 64(8):2107-2118

Post WM, Emanuel WR, Zinke PJ, Stangenberger AG (1982) Soil carbon pools and world life zones. Nature 298:156-159

Sala OE, Chapin FS, Armesto JJ et al. (2000) Biodiversity biodiversity scenarios for the year 2100. Science 287 : $1770-1774$

Solecki WD, Oliveri C (2004) Downscaling climate change scenarios in an urban land use change model. J Environ Manag $72: 105-115$

Solomon A (1986) Transient response of forests to CO2 induced climate change: simulation modeling experiments in eastern North America. Oecologia 68:567-579

Sweeting MM (1993) Reflect ions on the development of karst geomorphology in Europe and a comparison with its development in China. Z Geomoph 37:127-136

van Vuuren DP, Edmonds J, Kainuma M, Riahi K, Thomson AKH et al (2011) The representative concentration pathways: an overview. Clim Change 109(1-2):5-31

Verburg PH, Soepboer W, Veldkamp A, Limpiada R, Espaldon V, SharifahMA (2002) Modeling the spatial dynamies of regional land use: the CLUE-S model. Environ Manag 30(3): 391-340

Vitousek P, Mooney H, Lubchenco J (1997) Human domination of earth's ecosystems. Science 277:494-499

Wang SJ, Li YB (2007) Problems and development trends about researches on karst rocky desertification. Adv Earth Sci 22(6):573-582 (In Chinese)

Wang SJ, Liu QM, Zhang DF (2004) Karts rocky desertification in South-West China geomorphology, land use, impact and rehabilitation. Land Degrad Dev 15(2):115-121

Wen MJ, Tang CJ (2005) Reserved resources of cultivated land in China. China Land Press, Beijing (In Chinese)

Whittaker R (1972) Evolution and measurement of species diversity. Taxon 21:213-251

Wu XQ, Cai YL, Zhou T (2011) Effects of land use/land cover changes on rocky desertification: a case study of a small karst catchment in Southwestern China. Energy Procedia 5:1-5

Xiong KN, Chen QW (2010) Discussion on karst rocky desert evolution trend based on ecologically comprehensive. Carsolog Sin 29(3):267-273 (In Chinese)

Yang D, Jiang ZC (2011) Characteristic of rocky desertification and comprehensive improving model in karst peak-cluster depression in Guohua, Guangxi, China. Proc Environ Sci 10 Part C (0): 2449-2452

Yang ZS, Liu YS, Bao GJ, Bao GJ, Li ZG, He YM (2006) Rehabilitation and sustainable use pattern of rocky-desertified land in Southwest China's poverty-stricken karst mountainous areas. J Mt Sci 3(3):237-246

Yang QQ, Wang KL, Zhang CH, Yue YM, Tian RC, Fan FD (2011) Spatio-temporal evolution of rocky desertification and its driving forces in karst areas of Northwestern Guangxi, China. Environ Earth Sci 64(2):383-393 
Yang QY, Jiang ZC, Ma ZL, Luo WQ, Xie YQ, Cao JH (2013) Relationship between karst rocky desertification and its distance to roadways in a typical karst area of Southwest China. Environ Earth Sci 70:295-302

Ying B, Xiao SZ, Xiong KN, Cheng QW, Luo JS (2014) Comparative studies of the distribution characteristics of rocky desertification and land use/land cover classes in typical areas of Guizhou province, China. Environ Earth Sci 71:631-645

Yu XX, Yang GS (2002) The advances and problems of land use and land cover change research in China. Prog Geogr 21(1):51-57 (In Chinese)

Yuan DX (1993) The karst study of China. Geological Publishing House, Beijing (In Chinese)

Yuan DX (1997) Rock desertification in the subtropical karst of south China. Z Geomoph NF 108:81-90
Yue TX (2010) Surface modeling: High Accuracy and High Speed Methods. CRC Press, Boca Raton

Yue TX, Fan ZM, Liu JY (2005) Changes of major terrestrial ecosystems in China since 1960. Global Planet Change 48(4):287-302

Yue TX, Fan ZM, Liu JY, Wei BX (2006) Scenarios of major terrestrial ecosystems in China. Ecol Model 199(3):363-376

Yue TX, Fan ZM, Liu JY (2007) Scenarios of Land Cover in China. Global Planet Change 55:317-342

Yue TX, Zhao N, Ramsey RD, Wang CL, Fan ZM et al. (2013) Climate change trend in China, with improved accuracy. Climat Change, pp 137-151 